\title{
The influence of recent Brazilian policy and legislation on increasing bee mortality
}

\author{
A influência da recente política e da legislação brasileira no aumento da mortalidade de abelhas \\ La influencia de la reciente política y legislación brasileñas en el aumento de la mortalidad de las
}

abejas

Received: 03/22/2021 | Reviewed: 03/31/2021 | Accept: 04/03/2021 | Published: 04/14/2021

\author{
Aline Nunes \\ ORCID: https://orcid.org/0000-0002-7758-2681 \\ Universidade Federal de Santa Catarina, Brasil \\ E-mail: alinenunes_bio@hotmail.com \\ Caroline Schmitz \\ ORCID: https://orcid.org/0000-0002-9806-252X \\ Universidade Federal de Santa Catarina, Brasil \\ E-mail: carolineschmitz-bio@hotmail.com \\ Sidnei Moura \\ ORCID: https://orcid.org/0000-0003-1903-6735 \\ Universidade de Caxias do Sul, Brasil \\ E-mail: smsilva11@ucs.br \\ Marcelo Maraschin \\ ORCID: https://orcid.org/0000-0002-4146-4835 \\ Universidade Federal de Santa Catarina, Brasil \\ E-mail: m2@cca.ufsc.br
}

\begin{abstract}
The decline in bee communities in recent years has been a major concern worldwide. The increase in the mortality of these pollinators is related to several factors, the main one being the intensive use of pesticides in agricultural crops. Brazil is the world leader in use of pesticides since 2008 and recent changes in legislation have facilitated the commercialization of certain pesticides whose marketing has been banned in several countries. This review addresses how current Brazilian legislation on agrochemicals has influenced the increase in bee mortality. Under the current federal government, in 2019 and 2020, 474 and 493 new pesticides were registered in the country, respectively, some of them classified as highly toxic to bees. In addition, public policies in Brazil led by certain sectors of agribusiness have also contributed to increase the number of threats and the mortality of bees, making it difficult for the beekeeping sector to act in opposition. Understanding how these policies directly affect pollinator conservation allows decisionmaking to help mitigate their environmental and economic impacts in Brazil. Otherwise, without effective actions to mitigate the abusive use of pesticides, the numerous studies demonstrating its direct impacts on the bee's survival will be of no use.
\end{abstract}

Keywords: Pesticide; Agribusiness; Apis mellifera; Pollinators.

\section{Resumo}

O declínio nas comunidades de abelhas nos últimos anos tem sido uma grande preocupação em todo o mundo. O aumento da mortalidade desses polinizadores está relacionado a diversos fatores, sendo o principal deles o uso intensivo de agrotóxicos nas lavouras agrícolas. O Brasil é líder mundial no uso de agrotóxicos desde 2008 e as recentes mudanças na legislação têm facilitado a comercialização de alguns agrotóxicos cuja comercialização está proibida em vários países. Esta revisão aborda como a - legislação brasileira sobre agroquímicos tem influenciado o aumento da mortalidade de abelhas. No atual governo federal, em 2019 e 2020, foram registrados no país 474 e 493 novos agrotóxicos, respectivamente, alguns deles classificados como altamente tóxicos para as abelhas. Além disso, as políticas públicas no Brasil lideradas por determinados setores do agronegócio também têm contribuído para aumentar o número de ameaças e a mortalidade de abelhas, dificultando a atuação do setor apícola de oposição. Compreender como essas políticas afetam diretamente a conservação dos polinizadores permite a tomada de decisões para ajudar a mitigar seus impactos ambientais e econômicos no Brasil. Caso contrário, sem ações eficazes para mitigar o uso demasiado de agrotóxicos, os inúmeros estudos que demonstram seus impactos diretos na sobrevivência das abelhas serão inúteis.

Palavras-chave: Pesticida; Agronegócio; Apis mellifera; Polinizadores.

\section{Resumen}

La disminución de las comunidades de abejas en los últimos años ha sido una gran preocupación en todo el mundo. El aumento de la mortalidad de estos polinizadores está relacionado con varios factores, siendo el principal el uso intensivo 
de pesticidas en cultivos agrícolas. Brasil es el líder mundial en el uso de pesticidas desde 2008 y los cambios recientes en la legislación han facilitado la comercialización de ciertos pesticidas cuya comercialización ha sido prohibida en varios países. Esta revisión aborda cómo la actual legislación brasileña sobre agroquímicos ha influido en el aumento de la mortalidad de abejas. Bajo el actual gobierno federal, en 2019 y 2020 se registraron 474 y 493 nuevos pesticidas en el país, respectivamente, algunos de ellos clasificados como altamente tóxicos para las abejas. Además, las políticas públicas en Brasil lideradas por ciertos sectores de la agroindustria también han contribuido a incrementar el número de amenazas y la mortalidad de las abejas, dificultando que el sector apícola actúe en contra. Comprender cómo estas políticas afectan directamente la conservación de los polinizadores permite la toma de decisiones para ayudar a mitigar sus impactos ambientales y económicos en Brasil. De lo contrario, sin acciones efectivas para mitigar el uso abusivo de pesticidas, los numerosos estudios que demuestran sus impactos directos en la supervivencia de las abejas no servirán de nada.

Palabras clave: Pesticida; Agronegocio; Apis mellifera; Polinizadores.

\section{Introduction}

Interactions between pollinating plant and animal species are essential for preserving biodiversity and maintaining the functionality of terrestrial natural ecosystems and crops (Fantinato et al., 2018). It has been estimated that 300.000 plant species (almost 90\% of all flowering plants) require animal pollination to reproduce (Ollerton, Winfree \& Tarrant, 2011). For agricultural crops, pollination contributes by $75 \%$ to the production of world crops, representing an economic value estimated in $€ 153$ billion annually and contributing by $9.5 \%$ of world agricultural economic production (Giannini et al., 2014; Landaverde-González et al., 2017).

Bees have been considered the main pollinating agents in the nature, promoting both the spread of plants and the maintenance of genetic diversity in natural and agricultural crops environments (Woodcock et al., 2019). Brazil, one of the main producers of important crops worldwide, depends a lot on bee pollination services and it has been estimated that the economic value of these ecosystem services is around US\$ 12-14 109 (Santos, Otesbelgue \& Blochtein, 2018). According to the Brazilian Association of Honey Exporters (ABEMEL, in Portuguese), in 2017 Brazil have exported around 27 tons of honey, being the $9^{\text {th }}$ in the world ranking (ABEMEL, 2018). Regionally, the Southern region stands out as the largest producer (41.7\%), followed by the Northeast (27.5\%), Southeast (24.8\%), Midwest (4.5\%), and the North regions (1.6\%). According to the data from the 2017 Agricultural Census, 101,797 agricultural establishments produce honey in Brazil, with 2,158,914 hives (IBGE, 2017a). In 2016, Brazilian beekeeping exported about R $\$ 470$ million blossom honey (IBGE, 2017b). Thus, beekeeping is an important economic activity for the rural population, mainly for family farming. Apiculture has been considered an easy maintenance activity, with a low initial cost, also not demanding daily care and allowing the beekeeper having other sources of income. For this reason, this activity has been defined as an alternative to reduce unemployment, helping many families in the country (Sabbag \& Nicodemo, 2011; Lourenço \& Cabral, 2016).

However, despite the importance of beekeeping and its ecosystem services, bees are at continuous risk on a global scale. Indeed, studies have shown a great decline in bee populations in recent decades in many countries (Meeus et al., 2018) and numerous factors assist for that; among them the use of pesticides (Woodcock et al., 2017). In Brazil, a large decline in bee populations and the collapse in Apis mellifera colonies have been reported (Pires et al., 2016). In fact, over a 5-year period the loss of $\sim 1$ billion bees was estimated in Brazil, including honeybees, stingless bees, and solitary ones (Castilhos et al., 2019).

In 2019, 474 new pesticides were approved and registered in Brazil, the highest release since 2005, when data disclosure began (Brazil, 2021). In recent years, it has been allowed to launch in the market active ingredients highly toxic that are prohibited or even never disclosed by several countries (Serra et al., 2016; Kim, Kabir \& Jahan, 2017), many of them because are highly toxic also for human beings as already proven (Kim, Kabir \& Jahan, 2017). It is estimated that between 2000 and 2012 the use of pesticides grew by $288.41 \%$ and in 2017 the Brazilian market of those agrochemicals reached US\$ 8.8 billion (Friedrich, Souza \& Carneiro, 2018; Costa, Rizzotto \& Lobato, 2018). 
Considering the social and economic importance of beekeeping for the country and the relevance of pollination in agricultural areas, in addition to native areas (Vanbergen, 2013) this review addresses how Brazilian legislation has affected the increase of bee mortality in the country, as well as its consequences on the food production. For that, besides focusing on the Brazilian legislation, research data and scientific articles, especially in the last 10 years, have been considered to address how the ongoing government policy and the agribusiness sector have negatively impacted the apiculture in the country.

\section{Methodology}

For the elaboration of the article, a descriptive and systematic narrative review was applied in order to discuss the state of the art on the increase of bee mortality in Brazil and its direct relation with Brazilian politics and legislation. Because it is a complex and broad subject, this review model was adopted because it allows the interpretation and critical analysis of the authors (Rother, 2007). In this way, the data were collected in databases including: scientific books, archives of national and international research institutions and bodies, in addition to the Brazilian legislation. The Scientific Electronic Online Library (SciELO), Elsevier's Scopus databases, as well as the scientific journals accessed from the Coordination for the Improvement of Higher Education Personnel (CAPES, in Portuguese), available at https://www-periodicos-capes-gov-br.ezl.periodicos.capes.gov.br/ were used, between March 2020 and February 2021. In order to expand the results, keywords in Portuguese and English were used, such as bee mortality, pesticides, agribusiness, apiculture, pollinators, registration of pesticides, contamination in bees, and risks to pesticides.

\section{Bee Mortality}

In 1994, French beekeepers reported signs of anomalous bee's behavior in hives. It was noticed that many bees did not return to the hives and those that returned would gather in small groups on the ground, or yet they would be hovering disoriented in front of the hive. Evidences raised pointed to the contamination of bees by the Bayer's systemic insecticide imidacloprid (Maxim \& van der Sluijs, 2013). Further researches (Holder et al., 2018) on bee mortality in France also pointed to the use of the phenylpyrazole insecticide fipronil, a disruptor of the insect's central nervous system (CNS). Fipronil acts by blocking glutamate-gated chloride channels and also GABA-gated chloride channels, causing nerve and muscle hyperexcitation of insects even in low concentrations. Interestingly, restrictions on the use of this compound, as well as other insecticides (thiamethoxam and clothianidin, e.g.), started in 2008 in Italy Germany, and Slovenia, because of its relation with the bee death (Sgolastra et al., 2017). Over the years, numerous cases of bee populations decline have been reported, mainly in the USA, Europe, and Brazil, resulting from the intensive use of pesticides, causing the called "colony collapse disorder" syndrome (CCD) (Pires et al., 2016).

Bees are contaminated with pesticides while searching the environment for collecting pollen, nectar, and water (Lundgren, 2017). The chemicals used in pesticide formulations are ingested and absorbed by the bees' organism, causing toxic effects, such as physiological damages (Qi et al., 2020) or changes in behavior (Wang et al., 2017). Therefore, researches have associated different chemical groups to the rapid decline of bee colonies, e.g., organophosphates, organochlorines, pyrethroids, carbamates, and mainly neonicotinoids. The later are neurotoxic compounds that act on the CNS by binding to nicotinic acetylcholine receptors, leading to over-stimulation and paralysis (Christen, Bachofer \& Fent, 2017).

Tosi et al. (2018) investigated the Italian pollen visited by bees, revealing its contamination with the organophosphate chlorpyrifos. Likewise, analysis of bees collected in four locations in Spain during the citrus' flowering and fruit set periods, detected chlorpyrifos, dimethoate, and imidacloprid as the most common insecticides found in bee samples (Calatayud-Vernich et al., 2016). Importantly, these pesticides increased the mortality of these pollinators in citrus orchards.

In Mexico, the presence of organochlorine pesticides in honey and pollen samples from colonies of A. mellifera and Scaptotrigona mexicana, a stingless bee species was proved (Ruiz-Toledo et al., 2018). The authors report that for A. mellifera 
pollen organochlorines were detected in all samples, as for the honey ones a lower, but also outstanding value, was found, i.e., 93.3\% . For S. mexicana, $88.4 \%$ and $22.2 \%$ of the honey and pollen samples tested positive, respectively, for at least one pesticide. Besides, the most frequent pesticides detected were heptachlor, $\gamma-\mathrm{HCH}$, DDT, endrin, and DDE, which have long been banned from several countries.

Among the pyrethroid insecticides, bifenthrin was highly toxic to Apis mellifera, Apis cerana indica, and Trigona iridipennis species at $160 \mathrm{~g} \mathrm{ha}^{-1}$ (Govindaraj et al., 2017). Wang et al. (2017) point out that pyrethroid insecticides act on T-type voltage-gated calcium channels (VGCCs) in bee's brain cells, resulting in behavioral abnormalities, compromising swarming, feeding, learning, and acquisition skills of the insects.

In the case of carbamates, they act biochemically by reversibly inhibiting the activity of the enzyme acetylcholinesterase (AchE), leading to augmented amounts of acetylcholine in synapses in the brain and neuromuscular junctions, what results in cellular hyperexcitation (Gupta et al., 2017). For bees, carbamates have shown a toxic effect with a sublethal dose at $1.05 \mathrm{Mm}$ (Riva et al., 2018) and even a lethal effect $\left(\mathrm{LD}_{50}\right)$ (Lee et al., 2016). Studies have demonstrated the high degree of toxicity of different pesticides to bees (Table 1).

Table 1. Toxic concentration and mechanism of actions of pesticides in bees.

\begin{tabular}{|c|c|c|c|}
\hline Compounds & $\begin{array}{c}\text { Toxic } \\
\text { concentration }\end{array}$ & Mechanism of action & Reference \\
\hline Glyphosate & $1.25-5.00 \mathrm{mg} / \mathrm{L}$ & Slows the development of bee larvae and causes weight reduction & Vázquez et al. (2018) \\
\hline Paraquat & $1.00 \mathrm{ng} / \mathrm{kg}$ & $\begin{array}{l}\text { Affects the size of the enocytes and can cause damage to embryonic } \\
\text { development }\end{array}$ & Cousin et al. (2013) \\
\hline \multirow{2}{*}{ Imidacloprid } & $100 \mu \mathrm{l} / 50 \mathrm{~mL}$ & $\begin{array}{l}\text { Decreases in thoracic temperature and change in behaviour and feed- } \\
\text { ing }\end{array}$ & Azpiazu et al. (2019) \\
\hline & $3.90-39.0 \mu 1 / \mathrm{L}$ & Mortality rates above $90 \%$ in all tested exposure pathways & Gomes et al. (2020) \\
\hline Flupyradifurone & $\begin{array}{l}241 \pm 4.00 \\
\text { ng/bee/day }\end{array}$ & $\begin{array}{l}\text { Reduced bee survival, food consumption, thermoregulation, flight } \\
\text { success }\end{array}$ & $\begin{array}{l}\text { Tong, Nieh \& Tosi } \\
\text { (2019) }\end{array}$ \\
\hline Fipronil & $10.0 \mu \mathrm{g} / \mathrm{L}$ & $\begin{array}{l}\text { Caused dose-dependent reductions in the longevity of adult honey } \\
\text { bees }\end{array}$ & Holder et al. (2018) \\
\hline Flumethrin & $0.47 \mu \mathrm{g} / \mathrm{bee}$ & $\begin{array}{l}\text { Highly acute toxicity to newly emerged bees and in sublethal concen- } \\
\text { trations disturbs the physiological balance }\end{array}$ & Qi et al. (2020) \\
\hline \multirow{2}{*}{ Clothianidin } & $5.00 \mu \mathrm{g} / \mathrm{kg}$ & $\begin{array}{l}\text { Impacted energetic/nutrient homeostasis, including food consump- } \\
\text { tion, in a dose-dependent manner }\end{array}$ & Cook (2019) \\
\hline & $25.4 \mathrm{ng} / \mathrm{bee}$ & Significant reduction in body weight & $\begin{array}{l}\text { Yao, Zhu \& Adamczyk } \\
\text { (2018) }\end{array}$ \\
\hline \multirow[t]{2}{*}{ Thiamethoxam } & $10.0 \mathrm{mg} / \mathrm{kg}$ & $\begin{array}{l}\text { Intensify infection by Nosema ceranae, which increases the mortality } \\
\text { rate of bees }\end{array}$ & Tesovnik et al. (2020) \\
\hline & $100 \mathrm{ng} / \mathrm{g}$ & Reductions in bees and brood & Thompson et al. (2019) \\
\hline Sulfoximine & $5.00 \mu \mathrm{g} / \mathrm{dm}$ & Produced fewer workers and fewer reproductive offspring & $\begin{array}{l}\text { Siviter, Brown \& } \\
\text { Leadbeater (2018) }\end{array}$ \\
\hline
\end{tabular}


A survey (Castilho et al., 2019) performed from January 2013 to December 2017 reported 322 cases of bee mortality in Brazil (honeybees, stingless bees, and solitary bees), summing up 19,296 colonies, and estimating about 1 billion dead bees. The main cause for that was the exposure of bees to pesticides, mostly to fipronil, followed by the neonicotinoids clothianidin, imidacloprid, and thiamethoxam (Figure 1).

Figure 1. Chemical structures of fipronil (A), clothianidin (B), imidacloprid (C), and thiamethoxam (D).

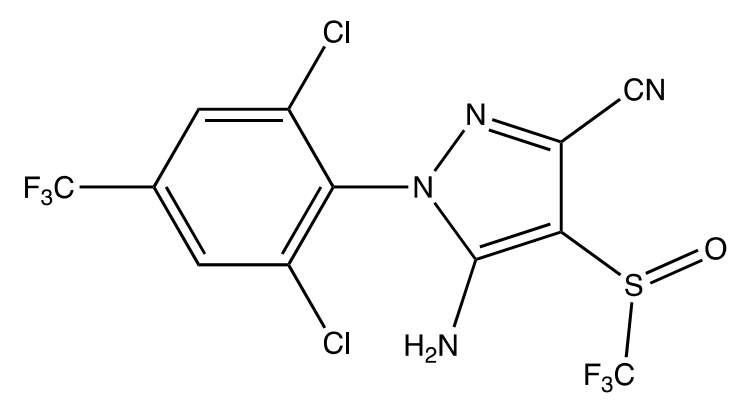

A<smiles>O=[N+]([O-])/N=C1\NCCN1Cc1ccc(Cl)nc1</smiles>

C<smiles>CN/C(=N\[N+](=O)[O-])NCc1cnc(Cl)s1</smiles>

B<smiles>CN1COCN(Cc2cnc(Cl)s2)/C1=N\[N+](=O)[O-]</smiles>

$\mathbf{D}$

Source: Authors (2021).

The use of high doses of pesticides for pest control is widely used in Brazilian crops and supported by legislation. An example is the culture of the melon, which uses several insecticides to control species such as the serpentine moth (Liriomyza spp.), the honeyworm (Diaphania hyalinata) L., and the earthworm (Diaphania nitidalis Cramer), among others. A study by Costa et al. (2014) evaluated the toxicity of insecticides used in the culture of melon in adults of Apis mellifera and observed that at the highest dosages recommended by the manufacturers for the culture the insecticides thiamethoxam $(0.1500 \mathrm{~g}$ i.a./L), abamectin (0.0180 g i.a./L), and chlorfenapyr (0.2400 g i.a./L) were extremely toxic to bees. Gomes et al. (2020) described that the recommended doses of the imidacloprid insecticide in the culture of melon caused mortality rates above $90 \%$ in all tested exposures (repellency, mortality, contact, ingestion, and flight) while pyriproxyfen caused significant mortality after exposure by contact and altered been flight capacity (Gomes et al., 2020). Importantly, two of the pesticides tested by these authors, i.e., abamectin, and imidacloprid, are on the list of active ingredients most commercialized in Brazil (IBAMA, 2019).

Between late 2018 and the beginning of 2019, it was estimated that more than 20 million bees have died only in Santa Catarina state (southern Brazil), mostly caused by the fipronil insecticide (CIDASC, 2019). In another southern state in Brazil, i.e., Rio Grande do Sul (RS), it has been shown that $80 \%$ of bee deaths result from the pesticides used in soybean crops. Indeed, between 2014 and 2017, 200 occurrences were reported in RS and in 70\% of the cases fipronil was the main pesticide detected, leading to the death of 480 million bees (Costa, 2019). 
In this sense, research institutions and bodies have proposed to identify cases of decline and colony collapse of bees in Brazil. The article entitled "Weakness and collapse of bee colonies in Brazil: are there cases of CCD?" (Pires et al., 2016) brought together researchers from Embrapa Genetic Resources and Biotechnology (Distrito Federal), Embrapa Meio Norte (Piauí), Paulista State University (UNESP, in Portuguese), Federal University of São Carlos (UFSCar, in Portuguese), United States Department of Agriculture (USDA) and Paulista Agribusiness Technology Agency (APTA, in Portuguese), in order to assess the "colony collapse disorder" syndrome, which has affected the United States and Europe. In the study, the authors confirm several cases of weakness, decline, and collapse of Apis mellifera hives in Brazil, mainly in the states of São Paulo and Santa Catarina. In addition, they point out that while one-third of the national territory has already been converted to agricultural lands, there is a great loss of natural vegetation and this impacts further increases of CCD cases. In addition to Brazilian universities and other research bodies involved in monitoring bee mortality, several institutions spread across the country have also carried out important researches to alert cases of bee death and colony collapses.

In addition to the studies herein cited linking the use of pesticides to the bee mortality around the world, many countries have implemented actions to minimize these harmful effects (Mengistie, 2016; Robin \& Marchand, 2018; Kwakye et al., 2019). However, Brazil has been moving in the opposite direction, which can have serious environmental and economic consequences, in addition to the damage to health, is considered a public health problem (Piccoli et al., 2016; Kim, Kabir \& Jahan, 2017; Pignati et al., 2017; Queiroz et al., 2019).

\section{Brazilian Legislation and its Relation with the Increased Release of Pesticides and Bee Mortality}

In Brazil, agriculture is the main economic activity for many states, where the predominant model of production is based on agribusiness (Nasrala Neto, Lacaz \& Pignati, 2014). This model is characterized by large estates, high concentration of land ownership, monocultures, large-scale mechanization and infrastructure for storage, precarious working relationships, and an increasing over socio-environmental risk (IBGE, 2006; Nasrala Neto, Lacaz \& Pignati, 2014; Sousa et al., 2019).

Agribusiness was introduced in Brazil aiming to provide food security and sovereignty, but in a short time it showed to be substantially different from that initial goal, because economic factors proved to be more important. Currently, most agricultural goods produced by agribusiness are exported, either as commodities or in the form of non-food products (biofuels and ethanol, e.g.) (Friedrich, Souza \& Carneiro, 2018). Agribusiness is very important for the country's trade balance, reaching a record of US\$ $22410^{9}$ in exportation in 2019 and a commercial surplus of US\$ $8310^{9}$ (SECEX/MDIC, 2020).

Due to the economic importance of agribusiness, recent changes in the national legislation on the regulation for pesticide release seem to have adopted mainly economic criteria. Political pressures occur both in the bodies of the Legislative Branch and in those that regulate and release agrochemicals for marketing. The performance of lobbyists in Brazil is also very strong, as they are able to directly influence lawmakers for moving and fostering the market. Indeed, nowadays an increasing number of active ingredients and products, prohibited or even never released in other countries or globally, has been allowed to be marketed in Brazil and, apparently, there is no reason to suppose that such a scenario is going to change in coming years (Serra et al., 2016).

The recent changes in criteria for disclosing the results of the Pesticide and Food Residue Analysis Program, along with the Bill Law 6299/2002, i.e., the "poison packet", that allows facilitating the release of pesticides in the country, demonstrate the confluence of economic forces linked to the multinational chemical industry to hide the risks of environmental and human being's contamination, also manipulating the information to consumers (Friedrich, Souza \& Carneiro, 2018).

The Bill Law 6299/2002 seems to be a strategy of transnational industries who see in Brazil, under continuous political crisis, the opportunity to commercialize pesticides not easily released in other countries. In the Brazilian congress, the group called "ruralists" is considered as a major player for the release of too many pesticides in recent years (Carneiro et al., 2015). 
Such a group has been known for their positions regarding the defense of landowner's interests, as they gather economical dominant classes and groups linked to rural, agroindustrial, and agribusiness activities (Bruno, 2017).

Another goal of interest of the ruralist group in the Brazilian congress focuses on the deregulation of the pesticide registration process. It has been aimed to create a National Technical Committee on Pesticides, which will define the raw materials and substances allowed or not to be used and commercialized in the internal market. Currently, the evaluation of safety parameters and toxicological traits of pesticide compounds is carried out by the National Health Surveillance Agency (ANVISA, in Portuguese) and by the Ministry of Agriculture, Livestock and Supply (MAPA, in Portuguese) (Carneiro et al., 2015). ANVISA has historically performed an important role in retaining the release of chemical compounds highly toxic to human beings and to the environment, but it is always exposed to political influences less compromised with the human health and environmental preservation.

The commercialization of pesticides is also facilitated because Brazil has adopted a policy of tax exemption guaranteed by the current legislation, where producers of commodities are the biggest beneficiaries. Thus, small producers are forced to use pesticides, as other forms of production are not considered competitive enough to receive government incentives, also reducing the number of farmers who would like to adopt agroecological production systems (Serra et al., 2016). Besides, for producers using pesticides there are substantial rural credit available, i.e., the State encourages the use of technological package that claims to represent "modernity" in agriculture (Araújo \& Oliveira, 2017).

Currently the use of pesticides is governed by the Law 7.802/1989, regulated by the Decree 7.074/2002, which replaced the Decrees 24.114/1934 and 98.816/1990. The law is considered one of the most advanced and protective of the environment and human health worldwide. However, some Draft Laws have sought to change the current legislation, which may represent a setback to the legal achievements (Almeida et al., 2017).

The Bill Law 3.200/2015 intends to modify the pesticide terminology to a "phytosanitary defensive product", which allows to minimize or even cancel the perception of intrinsic toxicity that these substances represent. Another factor targeted by the aforementioned Bill Law is the loss of decision-making power by the Ministries of Health and the Environment. Under current law, the responsibility for evaluating, reassessing, and registering a pesticide lies within three institutions: Ministry of Agriculture, Livestock and Supply, Ministry of Health, and Ministry of the Environment (MMA, in Portuguese). Bill Law 3.200/2015 intends to authorize the National Technical Commission on Phytosanitary to submit a conclusive technical opinion to requests for evaluation of new products, where it excludes several attributions of the Ministry of Health and MMA. If approved, it should cause a major setback in pesticide legislation, facilitating the release of new agrochemical, without determining what are the acceptable and unacceptable risks to human beings (Almeida et al., 2017).

In 2019, Bill Law 4146 aimed at to add legal provisions to Law 7.802 of 1989, introducing concepts related to new products, equivalent products, and risk assessment, establishing new procedures concerning the classification and registration of products. In this Bill Law, the inclusion of clearer concepts about risk assessment would represent an advance in pesticide legislation, as it would not only consider the toxicological class of the substances, but also the probability of damage to health or the environment (Federal Senate, 2019). On the other hand, it will depend on whether the law will not be used simply to speed up the process of releasing new substances.

In 2019, the first year of the Bolsonaro government, 474 new pesticide were registered, of which 448 (94.5\%) are generic ones from other products with active ingredients already used. Such a release was the largest one, surpassing the records of 2018 where 449 pesticides were registered. Importantly, for the released assets, 110 were considered extremely toxic, 52 highly toxic, 170 moderately toxic, and 171 with other classifications. In 2020, 493 new pesticides were launched, $4 \%$ more than in 2019. Thirteen pesticides are unprecedented in the country and 480 are generic of active ingredients already launched (Figure 2). 
Figure 2. Number of pesticides released in Brazil from 2005 to 2020.

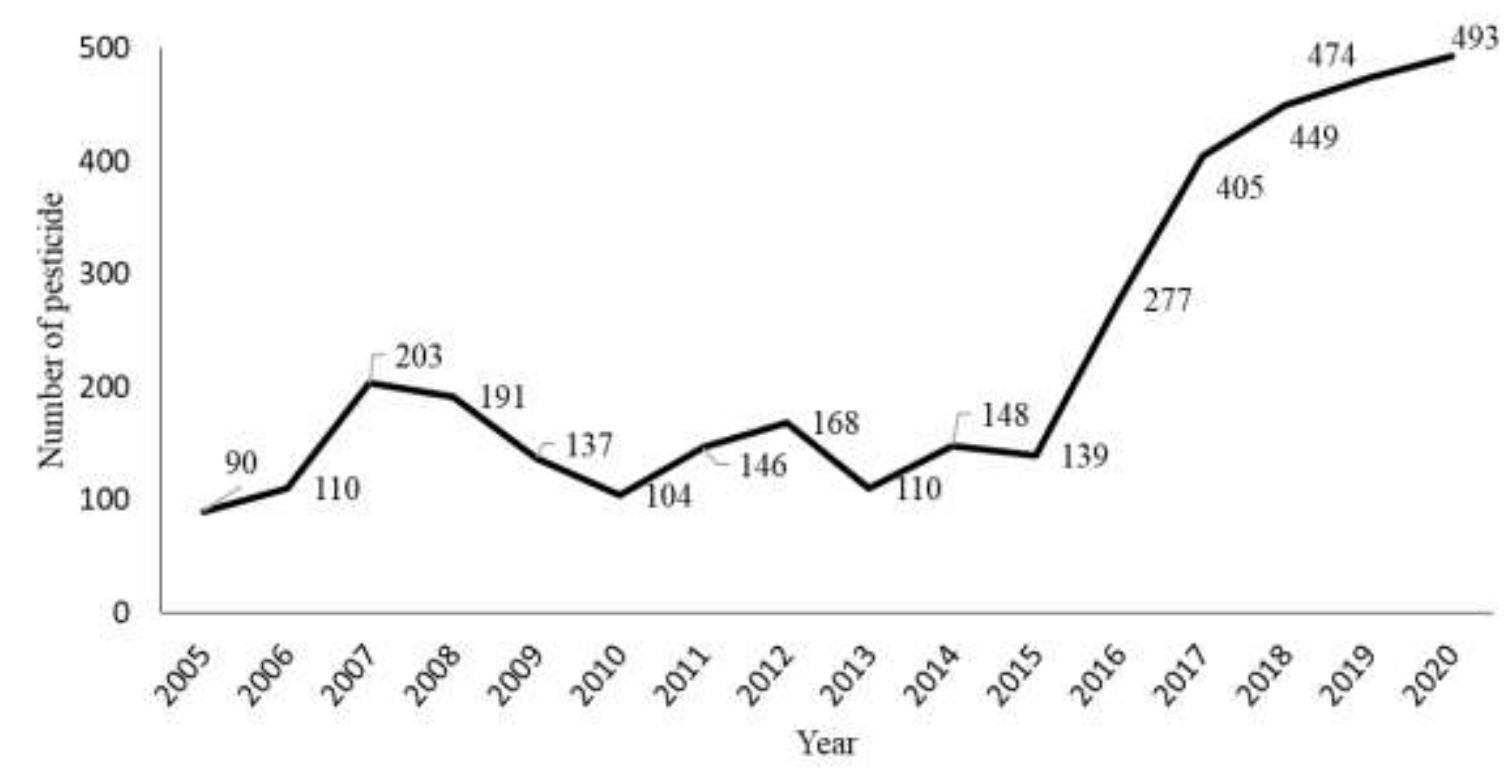

Source: Brazil (2021).

Among the releases in 2019, 26 products are considered new pesticides, with no previous release of generics, among which are florpirauxifene-benzyl, fluopiram and dinotefuran. The later one is a neonicotinoid insecticide never approved to be marketed in the European Union and currently under reevaluation in the USA, because of the high risk offered to bees and other pollinators. Azab and Morsy (2017) demonstrated that in higher concentrations $\left(1 \mathrm{Fx} 10^{-1}\right.$ and $5 \mathrm{Fx} 10^{-2}, \mathrm{~F}=$ recommended field rate in ug active ingredient $\mathrm{mL}^{-1}$ ), dinotefuran caused $100 \%$ of bee mortality after one day of exposure. Corroborating these data, Yasuda et al. (2017) shown that among the neonicotinoid's insecticides acetamiprid, imidacloprid, clothianidin, thiamethoxam, and dinotefuran, the latter was the most toxic for bees $\left(\mathrm{LD}_{50}, 1.4 \mathrm{ng} / \mathrm{bee}\right)$.

In Brazil, six products were also recently released based on the active ingredient sulfoxaflor, a new sulfoximine class insecticide, and three more containing lambda-cyhalothrin (pyrethroid) and sulfoxaflor, totaling nine products using that active ingredient (Agrofit, 2019). Interestingly, sulfoxaflor usage has been related to several sublethal impacts and increase in bee mortality worldwide (Siviter, Brown \& Leadbeater, 2018; Chakrabarti et al., 2020; Azpiazu et al., 2021). After many member states of the European Union have banned the use of neonicotinoids insecticides such as imidacloprid, clothianidin, and thiamethoxam outside greenhouse structures, sulfoxaflor arrived on the market as a differentiated neonicotinoid, because it acts on the insect nicotinic acetylcholine receptor (nAChR) in a distinct manner relative to neonicotinoids (Millot et al., 2017).

Regarding the imidacloprid active ingredient, with 37 products registered in Brazil, it was the main asset found in food samples (16\% - 713 samples) assayed from 2017 to 2018, according to the Program for Analysis of Pesticides Residues in Food (Brazil, 2019). This neonicotinoid compound, as well as thiacloprid and clothianidin, have been associated with sublethal and lethal effects on bees (Woodcock et al., 2017; Raymann et al., 2018).

In Brazil, it is possible to note that the sectors of agribusiness and beekeeping have opposite interests regarding environmental issues, even though the ecological service, i.e., pollination, provided by bees benefits the former sector. In fact, pollination of crops is beneficial for beekeepers to produce honey and other bee products, as for farmers pollination service contributes to increasing the market value of their products, because both the quantity and quality of fruits and seeds increase when pollination is performed by bees (Santos, Otesbelgue \& Blochtein, 2018). Thus, it is considered of great importance and mutual gains that those sectors can determine actions to minimize damages caused to pollinators by pesticides. However, from what was presented in the study, it can be seen that the current agribusiness sector's way of thinking makes it difficult to change the 
conventional management of cultivation systems, even though the damage to crop yields resulting from pollinator mortality has already been predicted long ago, especially for bees (Vanbergen, 2013; Novais et al., 2016).

Thus, is urgently necessary the adoption of sustainable alternatives to agrochemicals for pest control that mutually benefit the two sectors, such as the development of organic production systems combining pest management strategies through biological control and natural insecticides, such as botanicals and oils essentials (Santos, Otesbelgue \& Blochtein, 2018). In this sense, organic and agroecological production have served an increasingly growing market niche, mainly related to the maintenance of health and food quality (Abreu et al., 2012; Moraes \& Oliveira, 2017). The total area of organic crops land in the world has increased a lot in the world in recent year. For example, in 2017, 69.8 million hectares were registered dedicated to this activity and organic food and beverages markets reached $\$ 97$ billion. The practice of this cultivation model is carried out in 181 countries, with approximately 2.9 million farmers engaged (Willer \& Lernoud, 2019). In Brazil, from 2006 to 2017, the number of agricultural establishments with organic certification grew by more than $1,000 \%$, from 5,106 to 68,716 (IBGE, 2017a). However, in Brazil, there is a lack of incentives by the current Federal government to expand organic agriculture, as is the case in Europe, which has its growth stimulated by government programs and goals. Since the 1990s, there have been incentive programs for environmental protection in Europe, along with subsidy policies and targets for sustainable food production to support farmers. The organic market in Europe broke records in 2017, reaching 37.3 billion euros and the goal is that more and more farmers are making the transition from conventional to organic cultivation, transforming Europe into a model for the world (Willer \& Lernoud, 2019).

With the ongoing scenario, the implementation of public policies that encourage the production of organic systems must be seriously considered, in order to protect pollinators and pollination services. In this sense, the report by Diks et al. (2016) lists 10 essential public policies for the protection of pollination services and one can highlight 5 items directly related to incentives to organic systems production, such as 1) raising the regulatory standards for pesticides, 2) promote integrated pest management, 3) develop incentives, such as insurance schemes to help farmers to benefit from ecosystem services, 4) recognize pollination as an agricultural input in extension services, and 5) finance participatory research to improve yields in organic, diversified, and ecologically enhanced agriculture.

\section{Conclusion}

Agribusiness in Brazil is undoubtedly a booming sector, with important contribution to the balance of trade, but also with serious impacts on the environment and for the beekeeping sector. With decision-making actions based mainly on economic interests, the ruralist bench has acted in modifying legislation without considering the risks that conventional cultivation systems offer to the environment and human and animal health.

As demonstrated in the review, numerous studies have recursively proven that pesticides are lethal to pollinators, such as bees, who are primarily responsible for maintaining the genetic diversity of natural and agricultural crops. Considering the risks involved, proposing practices to minimize the impacts caused by pesticides in the country is urgently necessary, especially in the current unprecedented scenario where 474 pesticides were recently released, the highest rate ever seen.

Therefore, it is important to first emphasize the need for effective public policies to protect bee species in all Brazilian

states. Regulations and laws must be based on research carried out inside and outside the country. Several studies are carried out by research institutions and bodies; however, they are not taken into account for the construction of national strategies for the preservation of beekeeping.

The interaction between the agricultural and beekeeping sectors can be very beneficial for the development of strategies and collaboration for mutual growth, with no prejudice for any of the areas of activity. For the agricultural sector, it is urgent to 
include rules that prevent the registration of pesticides already banned in other countries. Besides, in the case of pesticides currently released in the country, greater inspection is necessary to control their usage.

Finally, the measures above mentioned can help to minimize risks to pollinators, but the impact on the use of pesticides will not be resolved yet. Therefore, the adoption of environmentally friendly practices is extremely necessary, especially in food production systems. In Brazil, organic production systems have been widely adopted in family farming systems but need greater encouragement and support for expansion by federal government agencies. Thus, as long as current interests and political forces remain active in Brazil, the increase in bee mortality will most likely continue to occur.

As a suggestion for future work, one can emphasize the need for researches aiming not only at the mortality of Apis mellifera bees, but also at other native bees and other pollinators. Likewise, there is a need to expand studies focusing on low toxicity chemical compounds, as these can impact non-target insects, leading to behavioral change and/or lethality.

\section{Acknowledgments}

To the Coordenação de Aperfeiçoamento de Pessoal de Nível Superior (CAPES) for granting the scholarship to A. Nunes and C. Schmitz. The research fellowship from CNPq (process $n^{\circ} 304657 / 2019-0$ ) on behalf of M. Maraschin is acknowledged.

\section{References}

ABEMEL. (2018). Associação Brasileira dos Exportadores de Mel. Setor apícola brasileiro em números: Inteligência comercial. https://brazilletsbee.com.br/INTELIG\%C3\%8ANCIA\%20COMERCIAL\%20ABEMEL\%20-\%20JANEIRO2018.pdf

Abreu, L. S., Bellon, S., Brandenburg, A., Ollivier, G., Lamine, C., Darolt, M. R., \& Aventurier, P. (2012). Relações entre agricultura orgânica e agroecologia: desafios atuais em torno dos princípios da agroecologia. Desenvolvimento e Meio Ambiente, 26, 143-160. 10.5380/dma.v26i0.26865

Agrofit. (2019). Consulta de Ingrediente Ativo. http://agrofit.agricultura.gov.br/

Almeida, M. D., Cavendish, T. A., Bueno, P. C., Ervilha, I. C., Gregório, L. D. S., Kanashiro, N. B. de O., Rohlfs, D. B., \& Carmo, T. F. M. do. (2017). A flexibilização da legislação brasileira de agrotóxicos e os riscos à saúde humana: análise do Projeto de Lei n 3.200/2015. Cadernos de Saúde Pública, 33(7), 111. $10.1590 / 0102-311 \times 00181016$

Araújo, I. M. M. de, \& Oliveira, Â. G. R. C. (2017). Agronegócio e agrotóxicos: impactos à saúde dos trabalhadores agrícolas no nordeste brasileiro. Trabalho, Educação e Saúde, 15(1), 117-129. 10.1590/1981-7746-sol00043

Azab, M., \& Morsy, A. (2017). Comparative risks of several insecticides towards honeybee workers. Asian Research Journal of Agriculture, 7(3), 1-7. doi:10.9734/ARJA/2017/38290

Azpiazu, C., Bosch, J., Bortolotti, L., Medrzycki, P., Teper, D., Molowny-Horas, R., \& Sgolastra, F. (2021). Toxicity of the insecticide sulfoxaflor alone and in combination with the fungicide fluxapyroxad in three bee species. Scientific Reports, 11, 1-9. 10.1038/s41598-021-86036-1

Azpiazu, C., Bosch, J., Viñuela, E., Medrzycki, P., Teper, D., \& Sgolastra, F. (2019). Chronic oral exposure to field-realistic pesticide combinations via pollen and nectar: effects on feeding and thermal performance in a solitary bee. Scientific Reports, 9(1), 1-11. 10.1038/s41598-019-50255-4

Brazil. (2021). Ministério da Agricultura, Pecuária e Abastecimento. Registros concedidos - 2005 - 2020. Brasília. https://www.gov.br/agricultura/pt-br/assuntos/insumos-agropecuarios/insumos-agricolas/agrotoxicos/informacoes-tecnicas

Brazil. (2019). Anvisa. Programa de Análise de Resíduos de Agrotóxicos em Alimentos (PARA): Relatório das amostras analisadas no período de 2017-2018. Brasília. https://www.gov.br/anvisa/pt-br/assuntos/agrotoxicos/programa-de-analise-de-residuos-em-alimentos

Bruno, R. (2017). Bancada ruralista, conservadorismo e representação de interesses no Brasil contemporâneo. In Questões agrárias, agrícolas e rurais: conjunturas e políticas públicas. E-Papers.

Calatayud-Vernich, P., Calatayud, F., Simó, E., Suarez-Varela, M. M., \& Picó, Y. (2016). Influence of pesticide use in fruit orchards during blooming on honeybee mortality in 4 experimental apiaries. Science of The Total Environment, 541, 33-41. 10.1016/j.scitotenv.2015.08.131

Carneiro, F. F., Delgado, G., Augusto, L. G. S., Almeida, V. E. S., \& Pessoa, V. M. (2015). Os impactos dos agrotóxicos no contexto do agronegócio. In A agricultura familiar e o direito humano à alimentação: conquistas e desafios. Brasília, DF: Câmara dos Deputados.

Castilhos, D., Bergamo, G. C., Gramacho, K. P., \& Gonçalves, L. S. (2019). Bee colony losses in Brazil: a 5-year online survey. Apidologie, 50(3), 263-272. $10.1007 / \mathrm{s} 13592-019-00642-7$

Chakrabarti, P., Carlson, E. A., Lucas, H. M., Melathopoulos, A. P., \& Sagili, R. R. (2020). Field rates of Sivanto ${ }^{\mathrm{TM}}$ (flupyradifurone) and Transform ${ }^{\circledR}$ (sulfoxaflor) increase oxidative stress and induce apoptosis in honey bees (Apis mellifera L.). PLoS ONE, 15(5), 1-15. 10.1371/journal.pone.0233033 
Christen, V., Bachofer, S., \& Fent, K. (2017). Binary mixtures of neonicotinoids show different transcriptional changes than single neonicotinoids in honeybees (Apis mellifera). Environmental Pollution, 220, 1264-1270. 10.1016/j.envpol.2016.10.105

CIDASC. (2019). Companhia Integrada de Desenvolvimento Agrícola de Santa Catarina. Cidasc defende restrição a agrotóxico que mata abelhas em reunião nacional. Florianópolis. http://www.cidasc.sc.gov.br/blog/2019/12/09/cidasc-defende-restricao-a-agrotoxico-que-mata-abelhas-em-reuniao-nacional/

Cook, S. C. (2019). Compound and dose-dependent effects of two neonicotinoid pesticides on honey bee (Apis mellifera) metabolic physiology. Insects, 10(1), 117. $10.3390 /$ insects 10010018

Costa, A. M., Rizzotto, M. L. F., \& Lobato, L. V. C. (2018). A questão dos agrotóxicos rompe os limites da ética da preservação da saúde e da vida. Saúde Em Debate, 42(117), 346-353. 10.1590/0103-1104201811700

Costa, E. M., Araujo, E. L., Maia, A. V., Silva, F. E., Bezerra, C. E., \& Silva, J. G. (2014). Toxicity of insecticides used in the Brazilian melon crop to the honey bee Apis mellifera under laboratory conditions. Apidologie, 45 (1), 34-44. 10.1007/s13592-013-0226-5

Costa, F. (2019). Agrotóxicos podem ter causado a morte de 480 milhões de abelhas no RS. Journal da Universidade UFRGS. https://www.ufrgs.br/jornal/agrotoxicos-podem-ter-causado-a-morte-de-480-milhoes-de-abelhas-no-rs/

Cousin, M., Silva-Zacarin, E., Kretzschmar, A., El Maataoui, M., Brunet, J.-L., \& Belzunces, L. P. (2013). Size changes in honey bee larvae oenocytes induced by exposure to paraquat at very low concentrations. PLoS ONE, 8(5), 1-7. doi:10.1371/journal.pone.0065693

Diks, L., Viana, B., Bommarco, R., Brosi, B., Arizmendi, M., Cunningham, S. A., Galetto, L., Hill, R., Lopes, A. V., Pires, C. S. S., Taki, H., \& Potts, S. G. (2016). Ten policies for pollinators. Science, 354(6315), 975-976. doi:10.1126/science.aai9226

Fantinato, E., Del Vecchio, S., Gaetan, C., \& Buffa, G. (2018). The resilience of pollination interactions: importance of temporal phases. Journal of Plant Ecology, 12(1), 157-162. doi:10.1093/jpe/rty005

Federal Senate. (2019). Bill No. 4146, 2019. Brasília. https://www25.senado.leg.br/web/atividade/materias/-/materia/137828

Friedrich, K., Souza, M. M. O., \& Carneiro, F. F. (2018). Dossiê Científico e Técnico contra o Projeto de Lei do Veneno (PL 6.299/2002) e a favor do Projeto de Lei que institui a Política Nacional de Redução de Agrotóxicos - PNARA. https://www.abrasco.org.br/site/wpcontent/uploads/2018/08/DOSSIE_NOVO_26_JULHO_Final-compressed2.pdf

Giannini, T. C., Boff, S., Cordeiro, G. D., Cartolano, E. A., Jr., Veiga, A. K., Imperatriz-Fonseca, V. L., \& Saraiva, A. M. (2014). Crop pollinators in Brazil: a review of reported interactions. Apidologie, 46(2), 209-223. 10.1007/s13592-014-0316-Z

Gomes, I. N., Vieira, K. I. C., Gontijo, L. M., \& Resende, H. C. (2019). Honeybee survival and flight capacity are compromised by insecticides used for controlling melon pests in Brazil. Ecotoxicology, 29(1), 97-107. 10.1007/s10646-019-02145-8

Govindaraj, R., Edward, Y. S. J. T., Kuttalam, S., \& Mohankumar, S. (2017). Contact toxicity of synthetic pyrethroid insecticides to honey bees Apis cerana indica Fab., Apis mellifera Linnaeus and Trigona iridipennis Smith in laboratory condition. Entomon, 42, $215-220$. http://entomon.in/index.php/Entomon/article/view/312

Gupta, R. C., Miller Mukherjee, I. R., Doss, R. B., Malik, J. K., \& Milatovic, D. (2017). Organophosphates and carbamates. In Reproductive and Developmental Toxicology (pp. 609-631). Elsevier. 10.1016/B978-0-12-811410-0.00037-4

Holder, P. J., Jones, A., Tyler, C. R., \& Cresswell, J. E. (2018). Fipronil pesticide as a suspect in historical mass mortalities of honey bees. Proceedings of the National Academy of Sciences, 115(51), 13033-13038. doi:10.1073/pnas.1804934115

IBAMA. (2019). Instituto Brasileiro do Meio Ambiente e dos Recursos Naturais Renováveis. Boletins anuais de produção, importação, exportação e vendas de agrotóxicos no Brasil. Brasil, Grandes Regiões e Unidades de Federação. http://ibama.gov.br/agrotoxicos/relatorios-de-comercializacao-de-agrotoxicos

IBGE. (2006). Instituto Brasileiro de Geografia e Estatística. Censo Agropecuário. Brasil, Grandes Regiões e Unidades de Federação. https://biblioteca.ibge.gov.br/visualizacao/periodicos/51/agro_2006.pdf

IBGE. (2017a). Instituto Brasileiro de Geografia e Estatística. Censo Agropecuário 2017 - resultados preliminares. https://censos.ibge.gov.br/agro/2017/

IBGE. (2017b). Instituto Brasileiro de Geografia e Estatística. Produção da pecuária municipal. https://biblioteca.ibge.gov.br/index.php/biblioteca-catalogo?id=784\&view=detalhes

Kim, K.-H., Kabir, E., \& Jahan, S. A. (2017). Exposure to pesticides and the associated human health effects. Science of The Total Environment, 575, 525-535. doi:10.1016/j.scitotenv.2016.09.009

Kwakye, M. O., Mengistie, B., Ofosu-Anim, J., Nuer, A. T. K. \& Van den Brink, P. J. (2019). Pesticide registration, distribution and use practices in Ghana. Environment, Development and Sustainability, 21, 2667-2691. 10.1007/s10668-018-0154-7

Landaverde-González, P., Quezada-Euán, J. J. G., Theodorou, P., Murray, T. E., Husemann, M., Ayala, R., Moo-Valle, H., Vandame, R., \& Paxton, R. J. (2017). Sweat bees on hot chillies: provision of pollination services by native bees in traditional slash-and-burn agriculture in the Yucatán Peninsula of tropical Mexico. Journal of Applied Ecology, 54(6), 1814-1824. 10.1111/1365-2664.12860

Lee, C.-Y., Jeong, S.-M., Jung, C.-E., \& Burgett, M. (2016). Acute oral toxicity of neonicotinoid insecticides to four species of honey bee, Apis florea, A. cerana, A. mellifera, and A. dorsata. Journal of Apiculture, 31(1), 51-58. 10.17519/apiculture.2016.04.31.1.51

Lourenço, M. S. M., \& Cabral, J. E. O. (2016). Apicultura e sustentabilidade: visão dos apicultores de Sobral (CE). Revista em Agronegócio e Meio Ambiente, 9(1), 93-115. 10.17765/2176-9168.2016v9n1p93-115 
Lundgren, J. G. (2017). Predicting both obvious and obscure effects of pesticides on bees. In Beekeeping - From Science to Practice (pp. 39-59). Springer International Publishing. 10.1007/978-3-319-60637-8_3

Maxim, L., \& van der Sluijs, J. (2013). Seed-dressing systemic insecticides and honeybees. In Late lessons from early warnings: science, precaution, innovation. European Environment Agency. https://op.europa.eu/en/publication-detail/-/publication/abc921c2-d517-445e-a661-504eeea4b564/language-en

Meeus, I., Pisman, M., Smagghe, G., \& Piot, N. (2018). Interaction effects of different drivers of wild bee decline and their influence on host-pathogen dynamics. Current Opinion in Insect Science, 26, 136-141. doi:10.1016/j.cois.2018.02.007

Mengistie, B. T. (2016). Policy-Practice Nexus: Pesticide Registration, Distribution and use in Ethiopia. SM Journal of Environmental Toxicology, 2(1), 1-13. $10.18174 / 391632$

Millot, F., Decors, A., Mastain, O., Quintaine, T., Berny, P., Vey, D., Lasseur, R., \& Bro, E. (2017). Field evidence of bird poisonings by imidacloprid-treated seeds: a review of incidents reported by the French SAGIR network from 1995 to 2014. Environmental Science and Pollution Research, 24(6), 5469-5485. $10.1007 / \mathrm{s} 11356-016-8272-\mathrm{y}$

Moraes, M. D., \& Oliveira, N. A. M. (2017). Produção orgânica e agricultura familiar: obstáculos e oportunidades. Revista Desenvolvimento Socioeconômico em Debate, 3(1), 19-37. 10.18616/rdsd.v3i1.3372

Nasrala Neto, E., Lacaz, F. A. de C., \& Pignati, W. A. (2014). Health surveillance and agribusiness: the impact of pesticides on health and the environment. Danger ahead! Ciência \& Saúde Coletiva, 19(12), 4709-4718. 10.1590/1413-812320141912.03172013

Novais, S. M. A., Nunes, C. A., Santos, N. B., D’Amico, A. R., Fernandes, G. W., Quesada, M., Braga, R. F., \& Neves, A. C. (2016). Effects of a possible pollinator crisis on food crop production in Brazil. PLoS ONE, 11(11), 1-12. doi:10.1371/journal.pone.0167292.g001

Ollerton, J., Winfree, R., \& Tarrant, S. (2011). How many flowering plants are pollinated by animals? Oikos, 120(3), 321-326. 10.1111/j.16000706.2010.18644.x

Piccoli, C., Cremonese, C., Koifman, R. J., Koifman, S., \& Freire, C. (2016). Pesticide exposure and thyroid function in an agricultural population in Brazil. Environmental Research, 151, 389-398. 10.1016/j.envres.2016.08.011

Pignati, W. A., Lima, F. A. N. S., Lara, S. S., Correa, M. L. M., Barbosa, J. R., Leão, L. H. C., \& Pignatti, M. G. (2017). Spatial distribution of pesticide use in Brazil: a strategy for Health Surveillance. Ciência \& Saúde Coletiva, 22(10), 3281-3293. 10.1590/1413-812320172210.17742017

Pires, C. S. S., Pereira, F. de M., Lopes, M. T. do R., Nocelli, R. C. F., Malaspina, O., Pettis, J. S., \& Teixeira, É. W. (2016). Enfraquecimento e perda de colônias de abelhas no Brasil: há casos de CCD? Pesquisa Agropecuária Brasileira, 51(5), 422-442. 10.1590/S0100-204X2016000500003

Qi, S., Niu, X., Wang, D. hui, Wang, C., Zhu, L., Xue, X., Zhang, Z., \& Wu, L. (2020). Flumethrin at sublethal concentrations induces stresses in adult honey bees (Apis mellifera L.). Science of The Total Environment, 700,1-12. 10.1016/j.scitotenv.2019.134500

Queiroz, P. R., Lima, K. C., Oliveira, T. C., Santos, M., Jacob, J. F., \& Oliveira, A. M. B. M. (2019). Sistema de Informação de Agravos de Notificação e as intoxicações humanas por agrotóxicos no Brasil. Revista Brasileira de Epidemiologia, 22, 1-10. 10.1590/1980-549720190033

Raymann, K., Motta, E. V. S., Girard, C., Riddington, I. M., Dinser, J. A., \& Moran, N. A. (2018). Imidacloprid decreases honey bee survival rates but does not affect the gut microbiome. Applied and Environmental Microbiology, 84(13), 1-13. 10.1128/AEM.00545-18

Riva, C., Sokolowski, M. B., Normand, J., Santos, J. S. O., \& Halm-Lemeille, M.-P. (2018). Effect of oral exposure to the acaricide pirimicarb, a new varroacide candidate, on Apis mellifera feeding rate. Pest Management Science, 74(8), 1790-1797. 10.1002/ps.4876

Robin, D. C., \& Marchand, P. A. (2018). Evolution of the biocontrol active substances in the framework of the European Pesticide Regulation (EC) No. 1107/2009. Pest Management Science, 75(4), 950-958. 10.1002/ps.5199

Rother, E. T. (2007). Revisão sistemática X revisão narrativa. Acta Paulista de Enfermagem, 20(2), 1-2. 10.1590/S0103-21002007000200001

Ruiz-Toledo, J., Vandame, R., Castro-Chan, R., Penilla-Navarro, R., Gómez, J., \& Sánchez, D. (2018). Organochlorine pesticides in honey and pollen samples from managed colonies of the honey bee Apis mellifera Linnaeus and the stingless bee Scaptotrigona mexicana Guérin from Southern, Mexico. Insects, 9 (2), 118. 10.3390/insects9020054

Sabbag, O. J., \& Nicodemo, D. (2011). Viabilidade econômica para produção de mel em propriedade familiar. Pesquisa Agropecuária Tropical, 41(1), 94-101. https://www.revistas.ufg.br/index.php/pat/article/view/10414

Santos, C. F., Otesbelgue, A., \& Blochtein, B. (2018). The dilemma of agricultural pollination in Brazil: Beekeeping growth and insecticide use. PLoS ONE, 13(7), 1-13. 10.1371/journal.pone.0200286

SECEX/MDIC. (2020). Secretaria de Comércio Exterior. Ministério da Indústria, Comércio Exterior e Serviços. Balança Comercial Brasileira e Balança Comercial do Agronegócio: 1997 a 2019. Brasília. https://www.udop.com.br/comercio-exterior-arquivos/12/13fev20_serie_historica_balanca_comercial_resumida_mapa_1997a2019.pdf

Serra, L. S., Mendes, M. R. F., Soares, M. V. A., \& Monteiro, I. P. (2016). Revolução Verde: reflexões acerca da questão dos agrotóxicos. Revista CEDS, 4, 225 .

Sgolastra, F., Porrini, C., Maini, S., Bortolotti, L., Medrzycki, P., Mutinelli, F., \& Lodesani, M. (2017). Healthy honey bees and sustainable maize production: why not? Bulletin of Insectology, 70, 156-160. https://docs.wixstatic.com/ugd/8e8ea4_de2a79351a004f0fb5fdc4e8c13c53e8.pdf 
Siviter, H., Brown, M. J. F., \& Leadbeater, E. (2018). Sulfoxaflor exposure reduces bumblebee reproductive success. Nature, 561(7721), 109-112. $10.1038 / \mathrm{s} 41586-018-0430-6$

Sousa, R. Á. D., \& Pereira, L. A. (2019). Agronegócio e Agrotóxico: uma parceria para o (in) sucesso da produção de alimentos. Revista ORG \& DEMO, 20(1), 27-44. 10.36311/1519-0110.2019.v20n1.03.p27

Tesovnik, T., Zorc, M., Ristanić, M., Glavinić, U., Stevanović, J., Narat, M., \& Stanimirović, Z. (2020). Exposure of honey bee larvae to thiamethoxam and its interaction with Nosema ceranae infection in adult honey bees. Environmental Pollution, 256,1-10. 10.1016/j.envpol.2019.113443

Thompson, H., Overmyer, J., Feken, M., Ruddle, N., Vaughan, S., Scorgie, E., Bocksch, S., \& Hill, M. (2019). Thiamethoxam: Long-term effects following honey bee colony-level exposure and implications for risk assessment. Science of The Total Environment, 654, 60-71. 10.1016/j.scitotenv.2018.11.003

Tong, L., Nieh, J. C., \& Tosi, S. (2019). Combined nutritional stress and a new systemic pesticide (flupyradifurone, Sivanto ${ }^{\circledR}$ ) reduce bee survival, food consumption, flight success, and thermoregulation. Chemosphere, 237, 1-9. 10.1016/j.chemosphere.2019.124408

Tosi, S., Costa, C., Vesco, U., Quaglia, G., \& Guido, G. (2018). A 3-year survey of Italian honey bee-collected pollen reveals widespread contamination by agricultural pesticides. Science of The Total Environment, 615, 208-218. 10.1016/j.scitotenv.2017.09.226

Vanbergen, A. J. (2013). Threats to an ecosystem service: pressures on pollinators. Frontiers in Ecology and the Environment, 11(5), 251-259. 10.1890/120126

Vázquez, D. E., Ilina, N., Pagano, E. A., Zavala, J. A., \& Farina, W. M. (2018). Glyphosate affects the larval development of honey bees depending on the susceptibility of colonies. PLOS ONE, 13(10), 1-19. 10.1371/journal.pone.0205074

Wang, Q., Diao, Q., Dai, P., Chu, Y., Wu, Y., Zhou, T., \& Cai, Q. (2017). Exploring poisonous mechanism of honeybee, Apis mellifera ligustica Spinola, caused by pyrethroids. Pesticide Biochemistry and Physiology, 135, 1-8. 10.1016/j.pestbp.2016.07.005

Willer, H., \& Lernoud, J. (Eds.). (2019). The World of Organic Agriculture. Statistics and Emerging Trends 2019. 20 ed. Research Institute of Organic Agriculture FiBL and IFOAM Organics International, Frick and Bonn. https://ciaorganico.net/documypublic/486_2020-organic-world-2019.pdf

Woodcock, B. A., Bullock, J. M., Shore, R. F., Heard, M. S., Pereira, M. G., Redhead, J., Ridding, L., Dean, H., Sleep, D., Henrys, P., Peyton, J., Hulmes, S., Hulmes, L., Sárospataki, M., Saure, C., Edwards, M., Genersch, E., Knäbe, S., \& Pywell, R. F. (2017). Country-specific effects of neonicotinoid pesticides on honey bees and wild bees. Science, 356(6345), 1393-1395. 10.1126/science.aaa1190

Woodcock, B. A., Garratt, M. P. D., Powney, G. D., Shaw, R. F., Osborne, J. L., Soroka, J., Lindström, S. A. M., Stanley, D., Ouvrard, P., Edwards, M. E., Jauker, F., McCracken, M. E., Zou, Y., Potts, S. G., Rundlöf, M., Noriega, J. A., Greenop, A., Smith, H. G., Bommarco, R., \& Pywell, R. F. (2019). Metaanalysis reveals that pollinator functional diversity and abundance enhance crop pollination and yield. Nature Communications, 10(1), 1-10. 10.1038/s41467019-09393-6

Yasuda, M., Sakamoto, Y., Goka, K., Nagamitsu, T., \& Taki, H. (2017). Insecticide susceptibility in Asian honey bees (Apis cerana (Hymenoptera: Apidae)) and implications for wild honey bees in Asia. Journal of Economic Entomology, 110(2), 447-452. 10.1093/jee/tox032

Yao, J., Zhu, Y. C., \& Adamczyk, J. (2018). Responses of honey bees to lethal and sublethal doses of formulated clothianidin alone and mixtures. Journal of Economic Entomology, 111(4), 1517-1525. 10.1093/jee/toy140

Wolowski, M., Agostini, K., Rech, A. R., Varassin, I. G., Maués, M., Freitas, L., Carneiro, L. T., Bueno, R. O., Consolaro, H., Carvalheiro, L., Saraiva, A. M., Silva, C. I., \& Silva, C. D. (2019). Relatório temático sobre polinização, polinizadores e produção de alimentos no Brasil. Editora Cubo, São Carlos. 